\title{
Konference o společenské odpovědnosti vědy a vysokých
} škol

\section{Jana Dlouhá}

Envigogika 11 (1) - Informace/ Information

Published/ Publikováno 16. 9. 2016

DOI: $\underline{10.14712 / 18023061.531}$

\begin{abstract}
Abstrakt
Konferenci s názvem Sustainability Transformations of Science Systems uspořádalo ve Vídni ve dnech 14.-15. 92016 Centrum pro otázky životního prostředí UK, ve spolupráci s mezinárodní sítí vysokých škol COPERNICUS Alliance a univerzitou BOKU (University of Natural Resources and Life Sciences, Vienna). Debaty o této změně vědeckého paradigmatu byly intenzivní, nebot' ovlivní role a funkce univerzit.
\end{abstract}

\section{Abstract}

The new role of science in society was discussed on the COPERNICUS Alliance conference Sustainability Transformations of Science Systems, in Viena, on September 14-15 2016. These debates were intense as transformations of science systems will affect the roles and functioning of universities. 
Konferenci s názvem Sustainability Transformations of Science Systems uspořádalo ve Vídni ve dnech 14.-15. 92016 Centrum pro otázky životního prostředí UK, ve spolupráci s mezinárodní sítí vysokých škol COPERNICUS Alliance a univerzitou BOKU (University of Natural Resources and Life Sciences, Vienna). Tématem byla věda udržitelnosti, tzv. Sustainability Science, což je nový teoretický koncept, který má v sobě zahrnovat rozmanité přístupy a diskurzy: nejen vědy prírodní, ale i společenské, a také hodnotová východiska a celospolečenské cíle - vyjadřuje tak současný trend otvírání vědy společnosti. Vychází z myšlenky udržitelného rozvoje, zachování životodárných systémů země i při uspokojování potřeb současných generací, jejich nároku na důstojný život. Mezi její základní cíle patří např́klad hodnocení vlivu prostředí na lidský blahobyt nebo využití nových metod k předpovědi chování některých přírodních a společenských systémů. Snahy po formulaci zásad vědecké práce $v$ "oboru" udržitelnosti začaly poměrně dávno (Friibergh Workshop, 2000), a pokoušeli jsme se je vyjádřit i na stránkách Envigogiky či jinde (Dlouhá, Moldan, 2007; Dlouhá, 2008). V poslední době ovšem tyto víceméně teoretické debaty sílí a získávají praktický rozměr - využití tohoto konceptu totiž významně podporují současné mezinárodní politiky výzkumu a vývoje a také evropské rámce podpory, např́klad program Horizon 2020. Začínají vycházet přehledové publikace, které shrnují poznatky z různých oborů a pokoušejí se sladit ekocentrický pohled s antropocentrickými poožadavky (Heinrichs et al., 2016).

Konference COPERNICUS Alliance, jako již pátá z řady každoročně pořádaných konferencí, se zaměřila na otázky rozvíjení společensky odpovědné vědy, analyzovala nové přistupy ve vědeckém bádání a jejich vliv na změny ve vysokoškolském vzdělávání, a reflektovala též proměnu role a postavení univerzit. Účastníci diskutovali o možnostech uplatnění této "udržitelné vědy" v souvislostech vnitřního uspořádání vysokých škol, jejich zapojení do života společnosti, nebo vysokoškolských a jiných politik.

Protože konference měla tentokrát výrazně interaktivní charakter, bylo v dvoudenním programu zařazeno jen několik přednášek klíčových odborníků či aktérů v dotčené oblasti, zato účastníci měli možnost navštívit četné kratší anebo delší workshopy, prezentace $v$ rámci posterové sekce; anebo shlédnout krátké filmy $k$ dané tématice. Na závěr mohli přispět $k$ formulaci společné Charty COPERNICUS Alliance.

Konference byla organizována jako ekologická akce (tzv. Green Meeting). Veškeré informace o konferenci jsou dostupné na stránkách COPERNICUS Alliance, viz http://www.copernicus-alliance.org/vienna2016.

\section{Literatura}

- Dlouhá, J., Moldan, B. (2007): Inter-, multi-, trans-disciplinarita - vymezení pojmů. Envigogika (2/2007), DOI: 10.14712/18023061.113, ISSN: 1802-3061. Dostupné z www <http://www.envigogika.cuni.cz/index.php/Envigogika/article/view/113/121>

- Dlouhá, J. (2008) Současná věda a její vztah k problémům lidstva. Theologická revue, roč. 79, č. 3-4 (2008), s. 377-399

- Friibergh Workshop on Sustainability Science (2000) Sustainability Science: Statement of the Friibergh Workshop on Sustainability Science, 11.-14 October, Friiberg, Sweden. 
- Heinrichs, H., Martens, P., Michelsen, G., Wiek, A. (eds.) (2016) Sustainability Science. An Introduction. Springer: Dodrecht, ISBN 978-94-017-7241-9, DOI 10.1007/978-94-017-7242-6 